Florida International University

FIU Digital Commons

FIU Electronic Theses and Dissertations

University Graduate School

3-29-2019

\title{
Identity Formation and the Stranger in William Shakespeare's Othello and The Merchant of Venice
}

Rodney Castillo

Florida International University, rcast179@fiu.edu

Follow this and additional works at: https://digitalcommons.fiu.edu/etd

Part of the Literature in English, British Isles Commons

\section{Recommended Citation}

Castillo, Rodney, "Identity Formation and the Stranger in William Shakespeare's Othello and The Merchant of Venice" (2019). FIU Electronic Theses and Dissertations. 4017.

https://digitalcommons.fiu.edu/etd/4017

This work is brought to you for free and open access by the University Graduate School at FIU Digital Commons. It has been accepted for inclusion in FIU Electronic Theses and Dissertations by an authorized administrator of FIU Digital Commons. For more information, please contact dcc@fiu.edu. 


\section{FLORIDA INTERNATIONAL UNIVERSITY}

Miami, Florida

IDENTITY FORMATION AND THE STRANGER IN WILLIAM SHAKESPEARE'S

OTHELLO AND THE MERCHANT OF VENICE

A thesis submitted in partial fulfillment of the

requirements for the degree of

MASTER OF ARTS

in

ENGLISH

by

Rodney Castillo

2019 
To: Dean Michael R. Heithaus

College of Arts, Sciences and Education

This thesis, written by Rodney Castillo, and entitled Identity Formation and the Stranger in William Shakespeare's Othello and The Merchant of Venice, having been approved in respect to style and intellectual content, is referred to you for judgment.

We have read this thesis and recommend that it be approved.

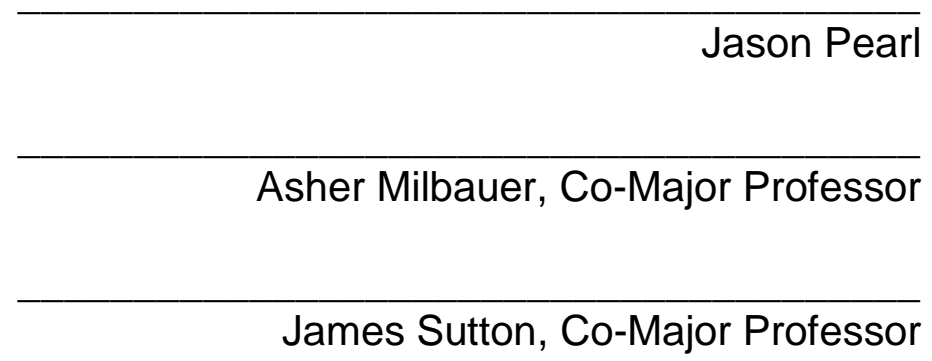

Date of Defense: March 29, 2019

The thesis of Rodney Castillo is approved.

Dean Michael R. Heithaus
College of Arts, Sciences and Education

Florida International University, 2019 


\section{DEDICATION}

To my parents Antonio and Marta Castillo, for they chose to endure the plight of the stranger and the hardships of the uprooted, so that their sons could have a better future. Their sacrifice is a debt that I will never be able to repay, and their love remains the sustenance of my soul. To Roel Rodriguez Jr., because you called me out and put an end to my procrastination. To Corrinne Lockamy; a light in times of darkness. You are truly amazing, and I am blessed to have met you. To my friend Avys Martinez, because without you the creation of this thesis would not have been possible. To FIU Honors College, for you provided me with an academic home, and with friendships that will last a lifetime.

I also dedicate this thesis to my professors - To Dr. Asher Milbauer, you gave me the vocabulary to articulate my own identity, and forever changed my approach to literature and to life. Thank you for being my mentor and advisor all these years. To Dr. James Sutton, for unlocking my passion for William Shakespeare. Because of you, England will always be a literary home to me. I am forever grateful for your guidance and friendship. To Dr. Kenneth Johnson, for showing me the world of transgression and hospitality. To Dr. Jason Pearl, you were the first to teach me close reading, and always encouraged me to aim high. To Dr. Heather Blatt, for guiding me through the rollercoaster that is Middle English, Medieval Literature, and digital text. Thank you for always being a source of support and inspiration. To Dr. Michael Gillespie, you gave me the tools to craft this thesis, and taught me to always to have a question ready. To 
Dr. Mark Kelley, for teaching one of the best seminars ever, and for being there for us.

To the Graduate English Association (GEA), your love and friendship made all the difference - Sherri, your dedication and selflessness created between all us bonds that will never break. You are one of the kindest souls I have ever met. Thank you. Oh, Danny, you are the joy of our group and your openness of heart is a refreshing oasis in an otherwise harsh world. I am fortunate to call you my friend. To Crystal, my fellow mage - your witty humor and insightfulness made every class all the better. To Amanda - you are the best of us, and we love you for it. To Ismael, cheers to all the good times, and know that you can always count on us.

Humanitas Supra Omnia 


\title{
ABSTRACT OF THE THESIS \\ IDENTITY FORMATION AND THE STRANGER IN WILLIAM SHAKESPEARE'S \\ OTHELLO AND THE MERCHANT OF VENICE
}

\author{
by \\ Rodney Castillo \\ Florida International University, 2019 \\ Miami, Florida \\ Professor Asher Milbauer, Co-Major Professor \\ Professor James Sutton, Co-Major Professor
}

The purpose of this thesis is to probe the question of the stranger as engaged by William Shakespeare in the plays Othello and The Merchant of Venice. It will introduce predominant views held during Tudor England towards foreigners and other marginalized groups, to ascertain the forces that influenced Shakespeare's works, and to provide a historical frame of reference. Further, the thesis will engage with issues of identity formation through postcolonial theories of cultural hybridity and hospitality as expressed by critical theorists Stuart Hall, Homi K. Bhabha, and Jacques Derrida. While racism and anti-Semitism are the most common readings of these two plays, I argue that in both cases Shakespeare is addressing the universal stranger. Further, the thesis will also seek to illustrate the viability to performance in a hyperconnected twenty-first century hybrid society, rejecting the idea of William Shakespeare as a hegemonic colonizer text devoid of relevance in modern times. 


\section{TABLE OF CONTENTS}

CHAPTER

PAGE

I. Hybridity, Mimicry, and Hospitality .........................................................

a. Racial Identity and the Stranger in Elizabethan England ..................14

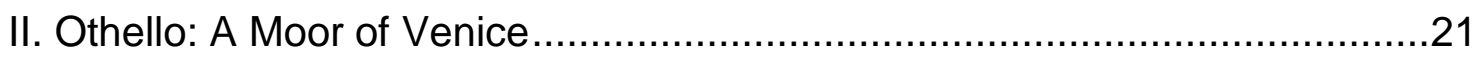

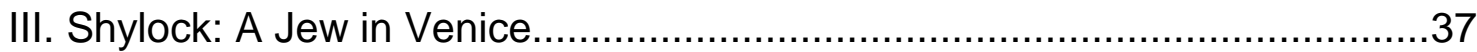

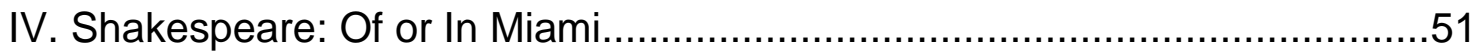

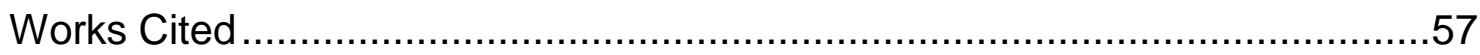




\section{Hybridity, Mimicry, and Hospitality}

"Nostalgia in reverse, the longing for yet another strange land, grew especially strong in spring." - Vladimir Nabokov, Mary

Identity formation, the plight of the stranger, and the transgressive nature of hospitality are concepts so labyrinthically interwoven with the human experience, that any attempt to adequately address them in a single work would be a reckless undertaking. Yet, for works that were meant as entertainment for the common people and perhaps also served as social commentary to some degree, William Shakespeare's plays can be found to be heavily-laden with discourse that skillfully interrogates these themes. Risking being accused of endorsing the academic heresy of Shakespearean universality, I believe it is undeniable that questions concerning identity formation, the plight of the stranger, and how hospitality informs them have been present throughout all human history in a kaleidoscope of ways. Still, before engaging with how Shakespeare treats these issues, through an analysis of Othello and The Merchant of Venice, it is imperative to unpack specific terminology and theoretical constructs to provide a level of clarity and delineation and frame the thesis within needed boundaries.

For the present work, the concept of identity will be used to address how humans view themselves individually as well as in relation to others; how social groups create a sense of uniqueness and separation as a way of definition. One 
approach to the formation of identity takes place in connection to the idea of nation and nationality, which in turn can be translated into home and homeland: I am my nation, I am my home. This thought embraces the idea of a natural sense of belonging, as people connect their identity with a shared culture or ancestral history within a determined space. Through the exultation of the unique incorporated within national identities, social constructs add moral imperatives to secure and seemingly humanize the preservation of the nation, the homeland. Although the primary purpose of the essay "Cultural Identity and Diaspora" by sociologist Stuart McPhail Hall is to engage in a conversation about cultural identity formation as it relates to the African Diaspora, he presents two conceptual models that prove useful in addressing how Shakespeare crafts his characters in Othello and The Merchant of Venice.

The first model he proposes seems comparable to the idea of identity being produced through nationhood previously mentioned, where below more superficial layers of the "self" a collective "true self" is crafted from a shared history, providing a "stable, unchanging and continuous frame of reference and meaning" (Hall 223). Such identity necessitates a claim to authenticity through an essential common core. Hall points out how this mode of cultural identity has been useful in the post-colonial reclaiming and rediscovery process for marginalized people, as they seek to clarify or unscramble their native past. This form of identity has also been the axle around which various diasporas such as the African and indigenous populations across the Americans and the Caribbean 
have tried to separate from the voices of their former masters while searching for their own.

One of the dangers of essentializing identity, however, is that of replacing one system of oppression with another one, no less prone to be guilty of similar sins. Claims to natural purity and originality are mythological at their core, as are any attempt to recover an unadulterated past through which one hopes to craft or retain an identity. In Mythologies, Roland Barthes rejects the concept of the "natural" through which myths are clothed, cloaked, and imbued with overdetermined meaning. While a myth does not necessarily hide things, Barthes says mythological signs habitually lie. He argues these distortions are infused with a sense of the eternal and the absolute, not natural, but driven and perpetuated through crafted histories (Barthes 108, 142). What constitutes the supposedly naturalized state of existence which Barthes rejects as mythological and through which Hall's first model of cultural identity seeks stability? Like the African diaspora that is Hall's target population, Othello and Shylock are transplants, foreigners enduring estrangement from the familiar and the struggles of not belonging. Joseph Conrad defines transplantation as "an unnatural state of existence" (Conrad 191). The Venetians in both plays exert a claim to a natural, cultural identity derived from their claim to a rigid common heritage, one which fundamentally excludes Othello and Shylock. Through this process, their state of existence is deemed unnatural. The mechanics of mythological and legalistic language as a conduit for forging cultural identities will be of significant 
value as the present thesis explores how the construct of the stranger is crafted in Othello and The Merchant of Venice.

Stuart Hall also contemplates a second model of cultural identity, different from the first one, while not dismissing the utility and importance of the former. By embracing the transformative power of time and events, Hall's second model presents a form of cultural identity that remains in perpetual flux. The effects history has had in reshaping any construct of origins makes cultural identity not "fixed in some essentialized past," but instead "a matter of 'becoming' as well as of "being"' (Hall 225). The act of "being" for Othello as a Moor and Shylock as a Jew creates a fixated identity easy for Venetians to alienate, and difficult for both characters to transcend. Hall's "matter of becoming" engages with the transformative effects the interactions between both groups have on identity. To view identity under this second model is to accept that a return to the idea of a crystalized past is not possible. What ensures a viable future is finding empowerment in the awareness of hybridity. To the individual or the collective, the past then becomes a point of reference by which to ascertain what they have become, but this does not entail rejecting the mutable present in favor of a supposedly adamantine past.

Writing about these ideas, Lawrence Grossberg reiterates that Hall's second model of cultural identity rejects the notion of "originary identities based in a universally shared origin or experience," as these are always incomplete, temporal, and "in process" (Grossberg 89). As Barthes would say, a rigid identity 
is mythological and therefore does not exist beyond the construct it creates to exercise power. Grossberg is also critical of the modern tendency of emphasizing the reconstruction of marginalized identities but admits that some work is being carried out to also see dominant identities as social constructs. This approach becomes essential when applying the concept of identity impermanence to William Shakespeare's Othello and The Merchant of Venice, as much of the conflicts found therein gravitate around a claim to superiority through purity, a rejection of hybridity, and a failure to embrace it. Further, Grossberg's critique of the neglectful treatment dominant identities receive will be helpful when discussing Shakespeare's relevance on the theatre stages of a post-colonial twenty-first century.

As imperial powers such as Britain, Spain, and the Portuguese subjugated and extracted wealth from their colonies, the idea of cultural superiority was fixated in their self-image, as well as in their treatment of those they saw as less civilized. Colonized people experienced a systematic devaluing of their culture, and new cultural guidelines were forced upon them, causing them to develop a merged identity as they found themselves struggling between cultures (Zohdi 147). The hybridity produced by these transactions is at the heart of Homi K. Bhabha's The Location of Culture, as he discusses an "in-betweenness" where the effects of dominant mythologies can be understood and dismantled. The inbetween space occupied by hybridity, which Bhabha defines as a "third space" is delineated by cultural, religious, and racial differences. While hybridity has endured the stigma of being impure and lesser, mostly attributed by those who 
claim purity for themselves, Bhabha celebrates the hybrid as a symbiotic event between the colonizer and the colonized, where it can act as an agent of disruption and questioning. Hybridity challenges the stranger-native binary and allows for other possibilities of transgression and transcendence. Thus, the third space becomes a place of negotiated inclusion, as it "initiates new signs of identity" (Bhabha, Location of Culture 1).

Bhabha's approach to hybridity is twofold. No individual or group can successfully claim to have a pure identity; not only is such "purity" mythological and fictitious in its rigidity, but hybridity becomes the "strategic reversal of the process of domination through disavowal (that is, the production of discriminatory identities that secure the 'pure' and original identity of authority) (Bhabha, Location of Culture 112). Through this lens, the present thesis will seek to deconstruct the Venetian's claims to "pure" identity, which they employ to engage with Othello and Shylock, and maintain their alienation. Still, if one aspect of hybridity reprobates the dominant group its claim to superiority through ancestral commonality, it also scrutinizes the identity claims of the marginalized groups under the same light.

Just as Stuart Hall's second model of cultural identity, hybridity also rejects the attempts of the transplanted, the uprooted, or even the exiled to retain or to (re)establish a Cartesian model of identity, of an essential self that seeks validation by reaching for an accessible unadulterated past. Endeavoring to do so only results in expressions of either nostalgia for what cannot be regained, or 
despair for the inability to belong in the new surrounds. Bhabha retains the postcolonial credentials of hybridity by arguing that the first to claim "unity and singleness of identity" are the colonial powers and dominant groups, and by establishing that hybridity exists prior to any form of unity (Easthope 146). Indeed, it subverts imperial structures through the presence of the other, such as Othello or Shylock, within the mainstream culture. While Easthope is critical of Bhabha's invitation to exist in a state of pure hybridity, the concept does not deny embracing a fixed identity. What it does is unmask such fixations as myths without hierarchical value.

Mimicry is another critical term that Homi Bhabha employs in his approach to identity under the postcolonial umbrella. The in-between spaces that an individual or group inhabit within the mechanics of a hybrid cultural identity are what enables Bhabha's "third space," existing as neither the entity prior to transplantation nor one who is now part of a diaspora - a space filled with ambivalence and contradictions (Zohdi 147). Like hybridity, ambivalence can affect both colonizer and colonized, as the interaction between the two creates mutations to their previous identity constructs. It is this ambivalence that Bhabha believes produces a sometimes unintentional yet subversive colonial mimicry, where the colonized appropriates part of the colonizer's identity - "the desire for a reformed, recognizable Other, as a subject of a difference that is almost the same, but not quite" (Bhabha, Of Mimicry and Man 126). Shakespeare, although writing centuries prior to Bhabha submitting these ideas to academic scrutiny, presents characters that operate within this ambivalent "third space." For 
Bhabha, colonial mimicry takes place in spaces of tension, somewhere between the norm and the transgressive. In his essay, he summons Jacques Lacan, who describes mimicry as neither suppression of difference nor an attempt to create harmony, but as a form of camouflage (Bhabha, Of Mimicry and Man 131). As Othello and The Merchant of Venice have experienced reworkings throughout centuries of productions, the issue of mimicry has acquired greater relevance, as postcolonial academics cast a skeptical look and seek to purge any emulation of colonial powers that have corrupted the identity of marginalized groups.

Cosmopolitanism, as far as it encompasses the idea of world citizenship, is not a preeminent trope within Othello or The Merchant of Venice. Othello and Shylock are transplants but do not overtly claim any world citizenship. However, William Shakespeare imbues these marginalized characters with subtle claims of belonging to humanity as a universal body. Immanuel Kant engages with the concept of universal hospitality, where the stranger should not be treated as an enemy, and instead be given limited or temporary rights of association with others because of "their common possession of the surface of the earth" (Kant 138). Neither Othello nor Shylock are transient characters passing through, and therein lies both their transgression and their plight. The interactions between the transplanted that stay and the mythological native/local in the plays reveal an insurmountable gap between the two groups. Jacques Derrida observes that Kant's concept of cosmopolitanism welcomes "the stranger, the foreigner, to the extent that he is a citizen of another country, that you grant him the right to visit and not to stay..." (Derrida, Politics and Friendship - A Discussion with Jacques 
Derrida). For Derrida, Kant's universalist formulation of hospitality is problematic because it is predicated on power structures and reinforces ideas of identity, determined by national interests, borders, and (not) belonging. Such identity should not be accepted as natural, but mythological, promulgated for general consumption as oppressive truths. Kant also contemplates the idea that "originally no one individual had more right than another to live in any one particular spot" (Kant 138). A variation of these words finds a dubious echo in The Merchant of Venice, where it is claimed that Shylock enjoys the same rights before the law as any Venetian does.

Much of the theory previously included gravitates around and grapples with the concept of the stranger and his/her plight. Thus, it is important to delineate what is meant by a stranger and how being a stranger informs the two Shakespearean plays in question. Attempting once more to steer clear of any claims to Shakespearean universality, some may say the process of othering that the stranger endures, whether labeled as aliens, foreigners, transplanted, or exiles seems to exist in a rotatory social structure. In this structure, emphasis or relevance is dictated by the time period, but none of the categories ever truly expire - race, gender, religion, nationality, and sexuality all seem to be a perpetual source of social tension. Through Kant's idea that no person or group has a superior claim to any parcel of land, one could argue that all humans are strangers - strangers who stayed and then crafted the notion of native belonging, to differentiate themselves from the stranger that arrived at a later point. This lens is useful to undermine structures of power, and it seems to be one that 
William Shakespeare works with. In his essay "The Stranger" Georg Simmel begins by marking a difference between the stranger and the wanderer. The latter is the category that fulfills Kant's call for hospitality. It is the individual imbued with the right to visit but not the right to stay. This transient quality of the wanderer seems to pose a lesser threat to the native population, as not only is he a well-defined outsider, but he is also easy to keep "othered." Itinerant traders, merchants, and sailors are a good fit for this category. However, both Simmel in his essay as well as Shakespeare in Othello and The Merchant of Venice, are interested in the non-transient stranger. While the wanderer comes and goes, for Simmel the stranger is the one that comes and settles; the former remains an outsider, but the latter becomes an insider that still does not belong despite his permanency within the "local" group.

The question of ownership, or at least the perception of ownership, is of importance as far as the mechanics of negotiations goes between natives and strangers. Simmel claims the dominant group sees the stranger as by nature unable to be "owner of land... not only in the physical but also metaphorically" (Simmel 144). When it comes to Othello, this issue becomes evident in his marriage to Desdemona. Although in different ways, neither those around him nor he himself ever fully accept his legitimacy as husband to a Venetian woman. Another mark imposed upon the stranger is that he is given tasks the natives reject or are unwilling to perform, evidence that they are neither fully embraced by the larger "native" group, nor are they wholly excluded from it (Karakayali 313). Shylock in The Merchant of Venice is a very accessible example of this, 
while Othello provides an interesting contrast as a stranger who is performing a job that many natives - one in particular - desire. Thus, the stranger exists in the in-between space of the hybrid, not only as far as their identity formation is concerned, but also in relation to their interactions with the society in which they have settled. A further point of interest with Simmel's model of the stranger is their supposed claim to objectivity through a lack of radical commitment towards the peculiarities of the native group. He does not claim that the stranger is fully detached or non-participatory, but rather, through lack of local entanglements, he stands uniquely positioned in a liminal place hedged between indifference and involvement (Simmel 145). Shakespeare challenges these ideas that somehow, the stranger is imbued with a lesser bias given his lack of full membership in the group: both Shylock's bitter views towards the Venetians, and Portia's exposition on mercy, appear to clash with Simmel's idea.

The last overarching theory through which much of this analysis of Othello and The Merchant of Venice will be shaped is that of hospitality and its transgressive elements. Judith Still opens her introduction to Derrida and Hospitality, by saying that as it is an everyday experience, "we all think that we know something about hospitality" (Still 1). As it is generally understood, hospitality is the act of welcoming the stranger into a space we "own," when we feel empowered to extend such invitation. As a paramount value among desertbased nomadic civilizations, where it was understood as a question of life or death, the idea of hospitality permeates the origins of the Western JudeoChristian tradition. However, because it acts as an integral component to the 
plight of the stranger, conceptual variations of hospitality are universally present throughout human history. For Judith Still, the stranger does not have to be an uprooted or dispossessed person; he could well be either a wealthy traveler or an impoverished refugee, and still fill the same space. It may be helpful here to recall Georg Simmel's category of the stranger that stays, as the primary interest of this thesis. Still also points out that the host community's reception of the stranger is seldom homogeneous or without contradiction, as such hosts express various degrees of either hospitality or what she refers to as inhospitality (Still 6). Othello is admired by some, hated by others, yet arguably othered by all, while the relational mechanics between Shylock and the Venetians are more nuanced and yet overt at the same time.

In Jacques Derrida's eulogy Adieu à Emmanuel Lévinas, the French philosopher argues that hospitality is not merely an ethical question but is ethics itself; the cultural ethos encompassing the public and private space, being there, and all forms of relation emanating from natives towards themselves or towards foreigners (Derrida, Adieu 50). Derrida also conceives of two forms of hospitality, one being unconditional and the other conditional. The present thesis concentrates on the latter, as Derrida himself declares the former an impossibility. Further, while hospitality is an extension of welcome from the host towards the stranger, it necessitates the presence of the outsider to empower the host's ability to be hospitable. Hospitality is therefore relevant only in relation to the plight of the stranger. 
Perhaps one of the most relevant aspects of Derrida's approach to hospitality is the questioning of the binary host-guest, and the dismantling of the idea that the welcome emanates from the host solely through his own agency as he draws identity-defining boundaries. Other critics who agree with this approach address the process of welcoming, but not as an act of power and appropriation. They see it instead as an act of exposure to the other that reveals the host's own condition as a refugee (Raffoul 216-17). Viewing Othello and The Merchant of Venice through the idea that dominant groups that perform as hosts towards strangers, are in turn, refugees themselves, may allow access to less apparent layers of the plays. Julia Reinhart Lupton writes that acts of hospitality are followed by a process of making room, a "clearing of a space in which a human appearing can occur" (Lupton 368). Yet, for Derrida hospitality precedes property, and the space the host claims as at-home and native is little more than "a 'land of asylum,' and hospitality" - given by one who is nothing more - or less - than a refugee who has ceased his wandering; a stranger who stayed (Raffoul 216). Room has been made for the host so that he can extend the welcome to the other. The notion of "making room" proves rather interesting when used to analyze the spaces created for Othello and Shylock by the Venetian society they inhabit. The Venetians in the plays seem to operate closer to a Kantian model of hospitality which sharply differs from that of Lupton and Derrida. Immanuel Kant's approach to hospitality necessitates a clear distinction between citizens and foreigners; the foreigner having limited rights insofar as the rights of the true and native citizen must remain preeminent (Schott 184-86) 
Hospitality as a process is bound by its intersubjectivity, unavoidably penetrating the space of all those involved. Thus, Kym Maclaren argues that "intersubjectivity is inherently transgressive" regardless if those involved are strangers or are well-known to each other. There is a mutual exchange resulting in a violent encroachment of one person's perspective upon another's, creating a state of perpetual transgression (Maclaren 19, 24). Derrida believes that the question of hospitality begins with language, in the imperative that asks of the stranger that he understand and speak the language of the host (Derrida, Of Hospitality 15).

Further, Derrida questions, even if the stranger spoke the host's language, would he still be alien? For Shakespeare's characters in Othello and The Merchant of Venice there seems to be no language barrier, though the Elizabethan author understood that communication was a point of tension between marginalized and dominant groups, and successfully illustrates such conflict. Also, Othello's presence as a Moor among Venetians, and his earned position of power, seem to transgress upon other characters through their reaction towards his existence in place and time.

a. Racial Identity and The Stranger in Elizabethan England

Many of William Shakespeare's detractors often accuse the author and his works of racism, anti-Semitism, and misogyny. Because some critics view Shakespeare, or the "business" which his works have propagated, and which go 
under his name, as an imperialist tool to perpetuate white hegemony, there is often a rush to scrutinize his works under anachronistic lenses, without considering the contextual framework that was the reality of Tudor England in the sixteenth and seventeenth centuries. I agree that it is necessary to apply modern thought to Shakespeare's plays to ascertain relevance and viability for twentyfirst-century audiences. Yet, an awareness of the social mechanics during the time these works were produced will not only provide further insight into the plays themselves, creating a more informed reader response, but such recognition might also serve as a conduit to strengthen the argument of their surprising ability to inform upon and speak to modern-day issues.

To entertain the idea of a society without a concept of race as we understand it in modern times may seem odd, as racism is a social malady that seems always to have been with us, inbred into our human fiber. The argument can be made that since the stranger is universally present across history, so is racism. Thus, for some, when it comes to William Shakespeare's plays, notably Othello and The Merchant of Venice, to claim an absence of racism in them seems an attempt to whitewash the texts and their author for the sake of reaffirming white dominance. While discrimination in its endless incarnations is an inseparable part of the transgressive nature of hospitality, the argument can be made that during some periods of human history, race as we now define it may not have been as much of a factor as other elements when constructing the specter of the other. Cultural rather than racial discrimination was the prevalent measure of distinction during much of the ancient Greek and Roman periods - 
Emperor Marcus Julius Philippus (Philip the Arab) was born in Syria, while Emperor Septimus Severus was of African-Moor ancestry, illustrating that cultural barbarism from the Roman point of view was simply anything found beyond the borders of the empire; as long as you were born "into" the empire, race was mostly immaterial.

After King Henry VIII broke ties with Rome and the Catholic Church a quest for reshaping what it meant to be English took hold of the country. Language became a powerful expression of identity, and the project of English self-representation through writing became the task of Elizabethan writers. Ian Smith argues that during the Tudor period one component of racial discourse was language and eloquence, which came to create a bond of inherited culture speaking English amounted "to a performative act of being English, a performance of the nation" (Smith 169, 173).

It was mentioned earlier that Derrida wrote about the burden imposed on the stranger, underscoring the demand of asking him to understand and speak the host's language. This resonates with Tudor England, where Smith argues that rhetorical eloquence helped "locate a discourse of racial difference in Early Modern England and separate between what was English and what was barbarous" (Smith 170). Shakespeare's very late Elizabethan play, The Life of Henry the Fifth, offers a prime example of this racializing linguistic turn. Having more lines in French than any other Shakespearean play, it presents Henry V's successful conquest of France and Princess Katherine's heart, echoing the 
triumphal rise of English as a language and an identity over the French, which had enjoyed dominion in England over eloquence and propriety for centuries. Henry uses Katherine's linguistic limitations to his advantage, while feigning lack of understanding. As is often the case with the stranger, cultural difference is in part expressed through language limitations, something Othello and his enemies are aware of in the play.

Skin color certainly played a role in the process of othering during Shakespeare's time. However, just like Jews and Moors were not codified only as religious groups, skin color represented cultural nationality. Two proclamations from Queen Elizabeth I, in 1596 and 1601, called for the deportation of Africans and blackmoores, as they were mostly "infidels, having no understanding of Christ or his Gospel" (UK National Archives). Some have used these proclamations to indicate racial bias and mistreatment against the African population in England at the time. Yet, I assert that these declarations were more about finding a scapegoat for some of the social problems and food shortages the queen saw her people were experiencing. Further, the proclamations were mostly ineffective, as they said masters had to give their consent for the Africans to be deported. They did not.

Skin color was not then a source of racism as much as it was a marker for xenophobia. Stephen Orgel counters what he calls a distorted view of race during the Elizabethan period, when seen through the prism of slavery and imperialism, arguing that blackness in a play like The Merchant of Venice is more a question 
of xenophobia than racism as the English understood it. Smith partially agrees with Orgel, admitting that alongside language, blackness is a racial signifier in Tudor England, but should not to be seen or understood through the lens of the post-transatlantic slavery trade (Smith, Race and Rhetoric 45-46). Historian Miranda Kaufmann explains in her recent book Black Tudors: The Untold Story that during the reign of Henry VIII many Africans lived free across the realms, and that records show some of them were baptized into, and married by the Church of England (Kaufmann).

After exposure to The Merchant of Venice, first performed in 1598, a modern reader or audience might well assume that William Shakespeare had access to a large and even thriving Jewish community living in England during his time. While it cannot be argued beyond doubt that the author may have encountered Jewish people at some point in his life, the fact remains that such a community did not exist within Tudor England. In July of 1290, King Edward I issued a royal decree ordering the banishment of all Jewish people from England. The edict remained in place until 1655, when Oliver Cromwell allowed their return (Byrne 2). It is estimated that around two hundred Jews lived in England during Shakespeare's time; most forcefully converted to Christianity or practiced their faith in secret. Different from the African and other strangers, the Jewish people carried a heavy burden placed on them due to the charge of deicide Christianity universally held against them. Their othering and persecution were not a question of racism, but religious animosity and cultural xenophobia. Representations of Jewish characters on the Elizabethan stage ranged from 
buffoonery to villainy, feeding distorted stereotypes to an audience that was unlikely to have met Jews as they went about their lives.

The plight of the strangers is not a realm inhabited solely by Africans and Jews in Tudor England. Refugees from Europe, particularly French Protestants known as Huguenots, experienced othering without presenting any physical or racial markings. These strangers were not even marked as (that) religiously different in Protestant England: their difference was almost entirely cultural and linguistic. William Shakespeare would have been well acquainted with their troubles, as he spent time boarding with them while in London. Between 1598 and 1612 Shakespeare lived with the Mountjoys, a French Huguenot family that had taken refuge in London. Several riots plagued Tudor England that dealt primarily with problems associated with these large groups of immigrants attempting to settle across the land; anti-alien riots took place from 1588 to 1595 , and before that, as early as in 1517 against foreigners living in the city of London. In Shakespeare's apocryphal play, Sir Thomas More, which was never performed given the sensitivity of the alien problem at the time, these words of the title character early in the play illustrates how the author felt towards the plight of the stranger.

You'll put down strangers, Kill them, cut their throats, possess their houses, And lead the majesty of law in lyam To slip him like a hound; alas, alas, say now the King, As he is clement if th'offender mourn, Should so much come too short of your great trespass As but to banish you: whither would you go? What country, by the nature of your error, 
Should give you harbour? Go you to France or Flanders,

To any German province, Spain or Portugal,

Nay, anywhere that not adheres to England,

Why, you must needs be strangers, would you be pleas'd

To find a nation of such barbarous temper

That breaking out in hideous violence

Would not afford you an abode on earth.

Whet their detested knives against your throats,

Spurn you like dogs, and like as if that God

Owed not nor made not you, not that the elements

Were not all appropriate to your comforts,

But charter'd unto them? What would you think

To be us'd thus? This is the strangers' case

And this your mountainish inhumanity.

(Sir Thomas More 2.4.102-123)

These lines express much of the public outrage for the aftermath of the 1590s riots which ended with four executions. Shakespeare terms barbarous and inhuman the behavior the Elizabethan society showed itself to be capable of, as they indulged in a process of othering, inflicting alienation and inhospitality on foreigners. Shakespeare presents here the universal plight of the stranger, limited not only to the refugees and other aliens the Londoners were protesting, but in a proto-Derridean fashion, extended outward to embrace all. He contemplates here our universal condition: all humans potentially are the stranger. 


\section{Othello: A Moor of Venice}

"We won't understand a thing about human life if we persist in avoiding the most obvious fact: that a reality no longer is what it was when it was; it cannot be reconstructed." - Milan Kundera, Ignorance

William Shakespeare extracts much of the source material for Othello from Giovanni Battista Giraldi (Cinthio)'s Gli Hecatommithi (1566), wherein one of the novellas tells of a villainous ensign who deceives a Moorish Captain and the virtuous Disdemona. Unlike Shakespeare's play, Cinthio begins his tale by declaring: "There once lived in Venice a Moor, who was very valiant and of a handsome person... highly esteemed by the Signoria" (Cinthio 2). The Italian author lacks the dramatic opening that Shakespeare added to his play, where lago, Roderigo, and Brabantio engage with the scandalous reality that Desdemona, a Venetian lady and daughter to a senator of the republic, has eloped and married "a Moor." Up in arms, Othello is brought before the Duke and is required to give a defense for his actions. It is revealing, if perhaps also curious, that Giuseppe Verdi, like Cinthio, chose to skip this Shakespearean introduction, opening his opera Otello (1887) with an exultant "Evviva! Evviva! Evviva!' as the city welcomes a triumphant Moor (Verdi). Unlike Shakespeare, Cinthio and Verdi open by providing their audiences with an unequivocal image of Othello - much beloved - being welcomed into Venice. 
It is pertinent to illustrate that Cinthio's Venice was a multicultural trade hub, where the presence of a Moor would not have been an oddity. Its geographic location granted the city the type of exposure that seems to have necessitated a flexible mechanics of tolerance between Venetians and foreigners. William Thomas' History of Italy (1549) claimed that all men, especially strangers, enjoyed a great deal of freedom in Venice, regardless of their nationality or religion, even if they believed in the devil (Thomas). Insofar he was Clerk of the Council to Edward VI, one may question his credibility towards the plight of the stranger, but other historical references seem to corroborate his narrative, at least in part. In the journals of The House of Lords and House of Commons during the reign of Elizabeth I, there is a 1593 entry showing that Privy Councilor Sir John Wolley took a stance against legislation that aimed to reduce and control the access of foreigners to London. He said that "Venice could never have been so rich and famous but by entertaining Strangers, and by that means have gained all the intercourse of the world" - quite a different opinion from the house member that spoke right after him, who asserted that the City of London was "great against these Strangers" (Dewes 506). Thus, Shakespeare was aware that the Venice he represents - which both is and is not London manifested a problematic relationship (one of shocking openness) with and to foreigners, and it is likely he adjusted the opening of Othello, and indeed the whole play, to reflect this.

The unnamed Moor of the first act, scene 1 (for Othello is not named until the second scene) is labeled "thick-lips," "an old black ram," "the devil," and 
"Barbary horse" $(1.1 .65,87,90,110)$. These debasing descriptors, used by lago and Roderigo to arouse Brabantio's indignation about what has happened to his daughter, would at first seem clear indicators of racism against Othello. Yet, within the first lines of the play, Shakespeare provides motives that have little to do with race, and much to do with passion and jealousy. As lago enlists Roderigo's aid to bring down Othello, he reveals his anger at being overlooked by the Moor for a promotion that he coveted, and for suspecting him of having slept with Emilia, his wife. The job goes to the Florentine Michael Cassio, towards whom lago then proceeds to express his disdain. Likewise, Roderigo calls Othello "thick-lips" as he contemplates the Moor's marriage to Desdemona, the woman he also loves.

The argument can be made that lago and Roderigo's case is in fact against strangers-at-large that have trespassed on what they believe is rightfully theirs through "native" right or birth. Initially, Brabantio discredits the duo's claim that he has been robbed by declaring they are standing in Venice, secured by his own claim to power and sense of belonging to that "idealized" city. For Roderigo, the space Brabantio, as senator of Venice, thinks secure has already been breached. The latter's idea of security derives from the illusion of ownership and sense of "at-homeness" Derrida seeks to dismantle in his writings on hospitality. The mirage that is Brabantio's Venice is thus reset by Roderigo's alarm in the middle of the night concerning the stranger that has come to rob the Venetian of what is his by right. 
Still, Roderigo pushes further by saying:

Your daughter, if you have not given her leave, I say again, hath made a gross revolt, Tying her duty, beauty, wit, and fortunes In an extravagant and wheeling stranger, Of here and everywhere. (1.1.131-35)

In her book Speaking of the Moor, Emily C. Bartels claims that by Roderigo making this declaration regarding the actions of Desdemona and Othello, Brabantio's Venice becomes also "a society that includes an extravagant and wheeling stranger" (Bartels 156). This inclusion, she writes, echoes the title of the play, which in its earliest form was The Moor of Venice, and connects the discrepancy between that title and Cinthio's opening line "a Moor in Venice." Not only is Othello in Venice, but Shakespeare declares him also as being of Venice, despite the Moor's incongruous provenance. This shift of prepositions makes Othello not a transient alien that Kant imbues with the right to hospitality conditional to an eventual departure, but Simmel's stranger that arrived and stayed. Roderigo's "stranger from everywhere" seems to encompass everyone who is not Venetian and is not aimed directly at Othello's African-Arab origins precisely. Albeit, Othello's othering is accentuated by his skin color, not necessarily seen as a sign of biological inferiority, but as an indicator of cultural difference.

How the Duke of Venice and the Senate conduct themselves towards Othello as he is accused demonstrates that he had been extended some degree of hospitality and station by the Venetians. He is hailed as "valiant Othello" by the 
Duke (1.3.48), a sentiment expressed repeatedly across the play. That the Duke calls the Ottoman armies a "general enemy" places Othello, not only within a shared bond within Christianity, but perhaps also counts him among the inhabitants of the city. Further, in the second act Montano deems Othello noble and praises him as a "worthy governor" (2.1.30), and in the final act Lodovico expresses shock when he sees the Moor strike Desdemona, as such behavior did not match the image of the noble and temperate Moor shared held by the Venetian senate. Even lago feels compelled to begrudgingly admit that Othello is "of a constant, loving, noble nature" (2.1.286). These are not descriptors to be given by a dominant group to someone held in racist contempt.

Indeed, the reader would be hard pressed to find throughout the play derogatory language aimed at Othello beyond what lago and Roderigo make use of. Only after the Moor has succumbed to jealousy, do other characters such as Emilia chide him. Even when Othello has lost himself to murder, there is regret in Lodovico's words when he refers to the Moor as "once so good, fall'n in the practice of a damned slave" (5.2.291-92). The fall referred to here should not be understood as alluding to a cultural fall aided by a racial connotation. Instead, it seems to reference Othello's own words, when he tells lago he descends from noble birth, and perfect soul $(1.2 .22,31)$. This is the fall Lodovico seems to be addressing. Thus, while racist elements are present across the play, they represent a general xenophobia Shakespeare places on the stage through this tension of praise and rejection. Why then, does Brabantio retract the hospitality extended generally to Othello? The Venetian senator rails against the marriage 
of his daughter to the Moor as unnatural, only possible through the "witchcraft" of which he accuses Othello. In marrying Desdemona, Othello has violated two precepts that disturbed the conditional hospitality extended to him by Venice, and by extension Brabantio.

The first precept of conditional hospitality Othello breaches is that of the one-sided agreement of separation between host and guest, or native and stranger. Through his union with Brabantio's daughter, Othello disrupts the pure identity her father claims for himself and the Venice in which he felt secure. The second claim is that by marrying Desdemona, Othello has acquired what was seen as Venetian property. As a stranger that stayed, the Moor may have been valiant and welcomed, but laying claim to Venetian soil through the body of his wife becomes a transgression too great for the likes of Brabantio, Roderigo, and those who adhere to the construct of natural exclusivity, to "nations" and the "nativism" they entail.

How Brabantio constructs his Venetian identity is further revealed by his inability to ever conciliate Desdemona's marriage with a stranger and his claim to what Roland Barthes would call mythological identity. Aside from his initial outrage at the union, the senator tells the Duke his daughter is dead, although the audience is aware she is physically alive (1.3.58). Desdemona's "death" upon marrying Othello is connected to a failure to perform the duty she admits owning to her father - which although absolute at some point in the past, she now declares divided. Desdemona links her duty to her father to her identity as 
Brabantio's daughter, and he the lord of such duty (1.3.181). This description insinuates their mutual connection to an identity based on a shared common ancestry, which she has inherited through her father, and has now broken with by marrying Othello. This is Stuart Hall's first model of cultural identity, that provides stability and "continuous frame of reference, and meaning" (Hall 223).

Brabantio concedes that Desdemona is Othello's wife but remains unyielding in his conviction that, if possible, he would keep his daughter away from the Moor with all his heart. He also takes comfort in the fact he has no other child $(1.3 .193,196)$. This seems a peculiar sentiment as it also entails the end of the familial line for Brabantio. Thus, it would be useful to contemplate to what degree he abhorred the possibility of identity hybridization, so much so that he would rather end his line than carry on this mixed, hybrid (bastard) stock. Despite the many changes Shakespeare visited upon Cinthio's original tale, he chose to retain the utter parental opposition to Desdemona's marriage. In the Italian narrative, Cinthio describes their efforts thus: "the parents of the lady strove all they could to induce her to take another husband" (Cinthio 2).

Although Cinthio's Gli Hecatommithi only affords the issue of parental consent a single sentence at the beginning of 'Disdemona and the Moor,' if the translation is to be trusted, the efforts of Disdemona's parents to avoid the marriage to the Moor were great and vigorous, as the idea of "striving" conveys. In Othello, Shakespeare develops this line further, having Brabantio reject the union most emphatically, "with all his heart," even to the point of death. During 
the final act, Gratiano, aside from expressing relief that Brabantio was spared the grief of witnessing Desdemona's untimely murder at the hands of Othello, elaborates that the senator's death was advanced by never overcoming or reconciling with the reality of his daughter's marriage (5.2.205-07). Brabantio lost the space of his "idealized Venice" in which his identity operated, by the realization not only of Othello's theft of his family's claim to a mythological Venetian heritage, but also by possibly understanding that indeed his Venice had been replaced by the Venice Roderigo conjured for him, with strangers everywhere. Venice is, in fact, a "grange."

To properly inform the argument of the second precept of hospitality Othello violates according to Brabantio, it may be necessary to address the meaning and framework through which the concept of intersubjectivity informs the process of this thesis. Intersubjectivity is not to be understood as the agreement between subjects that concerns a Cartesian model of self, where a subject is "presented as object of consciousness for the other," without direct encounter between each consciousness. Instead, intersubjectivity can be understood as the unavoidable affectations between subjects through interaction; where subjects are not objects of consciousness, but present as "perspectives that sweep us up and orient us towards the world" (Maclaren 24). Kym Maclaren argues that intersubjectivity is intently transgressive - a mutual exchange resulting in a violent encroachment of one person's perspective upon another's, creating a state of perpetual transgression. Further, while Canadian philosopher Lisa Guenther defines critical phenomenology as "rooted first-person accounts, 
similar to Maclaren, she resists the idea of a fixed subject with primacy over, or even unaffected by intersubjectivity (Salamon 9). Such an approach of "pure" identity would be considered by Barthes a myth.

Merleau-Ponty uses the idea of "coexistences," which is another way to view Derrida's dismantling of the host-guest binary. Through a mutual embodiment of being host and guest, the distance between subjects diminishes, and identity is thus forged as a byproduct of intersubjectivity that occurs as a result. This approach to identity is a transgressive assault on the Cartesian understanding of the self, where according to Maclaren, intimacy is impossible, as it negotiates intersubjectivity through separated agreeance of commonality (Maclaren 21).

The second precept of the conditional hospitality Othello transgresses against by marring Desdemona through a hybrid marriage is that of ownership. As previously mentioned, Georg Simmel proposes that the dominant group within a space they have claimed as home views the nature of the stranger as unable to be "owner of land... not only in the physical [sense] but also metaphorically" (Simmel 144). Because ownership anchors the stranger in place, and consequently removes much of the transient nature that serves as a guarantee of power for the host-native population, the rupture of this barrier results in a violent reaction in equal proportion to the claims on either side. In Desdemona, Othello finds a conduit through which, in the eyes of Brabantio, he has laid a claim of ownership in both senses. This idea does not substantiate the argument that 
Shakespeare endorsed gross misogyny in this play or many of his other works, beyond exposing much of what existed during the Elizabethan Period. The agency he imbues in his female characters, as well as the complaints they lodge against the limitations set by society against their gender, provide ample proof to the contrary.

In Desdemona, Shakespeare finds a unique opportunity to explore what it means for the identity process of the stranger to find a space to belong through the intersubjectivity of marriage. Brabantio and Roderigo see Desdemona as property of Venice that Othello has unrightfully claimed. For as long as Othello is a stranger without ownership claims, their relationship functions "in Venice," as Othello discharges the soldiering duties ascribed to him by the Senate. However, through his marriage to Desdemona, Othello began to function as being "of Venice," a nuanced shift able to create a profound difference in how those involved see the others and themselves.

Brabantio understands the perils of this transfer of status, even as he tries to apprehend Othello, stopped only by the Duke's summons. The senator is sure of the righteousness and necessity of his indignation, as he assures:

Mine's not an idle cause. The duke himself, Or any of my brothers of the state, Cannot but feel this wrong as 'twere their own; For if such actions may have passage free, Bondslaves and pagans shall our statement be.

The importance of every line quoted above towards a better understanding of the first act and the play as a whole can hardly be overstated. If for Derrida, 
hospitality precedes property, and a host's claim to space is null, for home is little more than "a 'land of asylum,' and hospitality" - given by one who is nothing more - or less - than a refugee who has ceased his wandering; a stranger who stayed (Raffoul 216), Brabantio is also aware of this. His cause is not an idle one because Roderigo's strangers from everywhere, represented by Othello, are actively introducing themselves in their society, not as wanderers passing by, but as sources of transgressive intersubjectivity. To further his cause, Brabantio makes his plight that of every Venetian, should Othello's action of marring (marrying) Desdemona be overlooked. He is not saying these words as an appeal to the parental instincts of the native population, but to raise the alarm that unless something is done now, their claim to a static authentic identity is in peril. Brabantio, disturbed at the scene painted by lago of his "daughter covered with a Barbary horse" (1.1.110), extends the horror of "nephews neighing" as a possibility to the rest of Venice. The imagery is not lost, beyond the physicality of the stranger being related to animals, but more importantly, the "neighing" refers to the language barrier made apparent by strangers. Derrida engages with language as the preface to the question of hospitality, and the burden imposed by hosts-natives upon their guests-strangers through the imperative of asking them to understand and speak the language of the host (Derrida, Of Hospitality 15). Ultimately, Brabantio refuses to embrace a Venice or a Venetian self that is temporal, incomplete, and always "in process" (Grossberg 89).

The Venetian senator prophesizes the doom that would befall the city if strangers are allowed to be "of Venice" - "Bondslaves and pagans shall our 
statement be" (1.2.99). The importance of this line is twofold. The more immediate interpretation is that this discloses Brabantio's passionate xenophobic views. Not only is his use of the word "bondslaves" recalling Othello's time in slavery, but he unequivocally declares that strangers, even if not transient wanderers, should never be considered "of Venice," as to do so would empower them with the right to rule on equal footing as those Brabantio see as true Venetians. The declaration is not a call to city-wide racism, albeit those may be its ultimate implications. By singling out those in slavery and practitioners of religions other than Christianity, Brabantio's call of exclusion is far more comprehensive than the singling out of Othello's race. He does not call for a ban or subjugation of strangers only of African or Arab provenance, but for the regulation of all those not of Venice.

The second implication the line has is its connection to Lodovico's words towards the end of the play, referring to Othello as "once so good, fall'n in the practice of a damned slave" (5.2.291-92). Here the word slave requires further unfolding as it reflects on how Shakespeare uses the term; for upon careful reading, the word seems to relate more to lago than to Othello (Heilman 111). Referring to lago, Montano calls him slave after the villain murders Emilia and runs away (5.2.244). Lodovico is the last character to use the term slave, and it is also to reference lago, as he commends Cassio to punish him (5.2.333). Even Othello, as he finds out the truth of lago's deceptions and betrayal accuses him: "O cursed, cursed slave!" (2.5.278). Shakespeare reconstructs the word slave to 
mean something beyond race or social status, for it is used to qualify strangers and would-be natives alike.

Othello is only slave-like when he murders Desdemona, and lago is labeled so when his deeds are brought to light. Further, lago uses the term slave as he calls after the man that has injured Cassio, whom he knows to be Roderigo. Calling Brabantio's words prophetic, Robert Heilman connects lago, ultimately labeled as slave, with the senator's concern that one day bondslaves and pagans would rule (Heilman 111). lago certainly does rule across the play through gross manipulation. Thus, the Elizabethan author equates the concept of the slave with that of evil, a person that has abused the transgressive nature of intersubjectivity, and has ruptured himself away through his actions towards others.

Prior to his fall and afterwards, Othello remains an alien to the society around him, and neither his noble birth or valiant deeds can change that perception in Othello himself or within Venetian society. Othello does not actively seek to exist within Stuart Hall's first model of cultural identity. As a baptized Christian inhabiting Venetian culture, Othello does draw on his heritage as a moor for self-definition, beyond how his physical characteristics inform who he is. At no point does the Moor express a desire to reclaim an identity lost by his presence in Venice. Only as Othello's character unravels through lago's deception, does the text have him reach back into his past to explain the present, and Desdemona's handkerchief becomes an object that bridges both. The 
process is a violent one and cannot provide Othello with the mythological stability promised by an essentialized identity rooted in his ancestral past.

Stuart Hall's second model of cultural identity provides a better option for understanding Othello, as it conceives the subject in a state of perpetual flux. The act of "being" for Othello as a Moor provides his enemies with a fixed target to alienate. It is important for the likes of Brabantio, Roderigo, and lago that he remains the Moor, irrevocably lascivious and dark by nature. For Othello, his conversion to Christianity and his life in Venice informs his identity as "a matter of becoming," experiencing transformation through an intersubjective process that leads him to a state of hybridity, something Brabantio is terribly afraid of and why he sees Desdemona as dead from the moment she forsakes his illusion that there is a stable and homogeneous Venice.

In the play, Othello is able to function with success as long as he is allowed to inhabit a hybrid identity - Homi Bhabha's third space where inclusion is negotiated. Zohdi calls this space one of contradictions and ambivalence (Zohdi 147). It could be argued that as a foreigner, Othello's position and rapport is an atypical case in Venice, which allows him to act as a subject to mimic the dominant group around him - Othello becomes dangerously Venetian. By embracing Christianity, marrying Desdemona, and operating within the Venetian social structures of temperance and civility, some would argue that Othello allows himself to be fooled into an erroneous sense of belonging. He admits to this in 
part, as he declares "for I am black" and not like them (3.3.263-65), trying to understand Desdemona's apparent betrayal.

Othello errs about the source of his fate, which is not fully inhabiting Bhabha's third space of hybrid identity. He will never be Venetian as Brabantio sees himself, nor will he ever be as he was prior to being uprooted from his homeland. Othello was right in embracing the in-betweenness that becoming "of Venice" offered, and his fall was not the product of a failed approach to hybridity, but a rejection by those who, in order to retain their sense of power and security, embraced their mythological claim to pure, unquestionably superior identity. Madness and violence overcome Othello once he sees himself no longer having any claims to the in-between space created by his deeds for, and relationship with Venice, as validated by his marriage to Desdemona. For Lodovico, lago is a viper and a villain, while Othello is rash an unfortunate (5.2.283-84). From the stranger that stayed, Othello becomes a rejected wanderer through the identity lago imposes on him. No longer "of Venice," the Moor asks: "where should Othello go?" (5.2.272).

The first and the final acts of the play enclose the core of Shakespeare's approach to Othello as a character and Venice as a society. Some argue that Othello's death is the result of a skin "too black for anyone to accept - to forget or to "forgive" and that "one's skin blots out one's soul" (Hogan 431) However, as a rebuttal to this view, which facilitates a racial twentieth-century reading of the play, I argued that Othello's death is the aftermath of a rejection of hybridity and 
the inescapable nature of intersubjectivity by some elements of Venetian society, which Shakespeare is mindful not to portray as the general status quo. Even when losing the in-between space that provided a space of validation to Othello, and succumbing to rage and murder under lago's rule, Shakespeare does not let the Moor go without redemption. Not only does Othello display deep remorse towards his deeds, but Cassio's last words in the play: "For he was great of heart" (5.2.361) evoke the Moor's noble character and perfect soul. 


\section{Shylock: A Jew in Venice}

"How can you expect a man who's warm to understand one who's cold?"

- Aleksandr Solzhenitsyn, A Day in the Life of Ivan Denisovich

It may seem as an anomaly for many a modern audience that, generally speaking, unlike the tragedy of Othello, The Merchant of Venice is placed under William Shakespeare's comedies. Although the witty romance, love overcoming obstacles, the humor, and the ending with a double wedding, are surely enjoyed by readers and theatre audiences alike, it is the character of Shylock that has captured and dominated the attention of those who encounter this play. Some would even argue that anything that happens after the court scene of act four feels pedestrian, almost as if to abate the intensity of what just took place. Shakespeare provides Shylock with lines of such immense power, that while the

character of the Jewish moneylender has become a controversial cornerstone of Shakespearean studies and performance, Antonio, who is the merchant of Venice, has been relegated to obscurity.

As previously discussed, the racism attributed to Othello is questionable, and ought to be challenged beyond the binary of imperialism versus postcolonial ideologies to better address the questions of modern audiences. However, it is undeniable that The Merchant of Venice is a play with antisemitic themes themes Shakespeare chose not to lessen or blur. To the question of whether the Elizabethan author was antisemitic or not, the best answer may be that to some 
degree, as were all those burdened by the trappings of medieval Christianity, he was. Yet, Shakespeare's crafting of the character of Shylock and the events around him indicate that his antisemitism should not be understood through a twentieth-century post-Holocaust lens. As humiliating and immoral as Shylock's forceful conversion to Christianity is at the end of the play, Shakespeare's solution, although grossly inadequate, was an attempt to humanize him refusing to make the character a typical source of ridicule, as was more often the case during his time. This is not to make the claim that The Merchant of Venice was a play where Shakespeare's main drive was to denounce the wrongs suffered upon the Jewish people by Christians, just like Othello should not be understood as the author calling for the end of all discrimination across the land. This is not so.

The first consideration for addressing the identity mechanics of this play, is to question how is Shylock an alien. During a Royal Shakespeare Company program in 1984, John Barton questioned David Suchet and Patrick Stewart about the Jewish component of Shylock and its interpretation in performances. Stewart asserted that "Shylock is essentially an alien, who happens to be a Jew," proposing that this view unlocks the character's true universality (Stewart). Andrew Tretiak agrees with Stewart and writes that in Shylock he sees a representative of all the foreign immigrants" (Tretiak 403). Countering this, David Suchet claimed that Shylock is an outsider because he is a Jew (Suchet). Indeed, it is difficult to divert the source of Shylock's plight in Venice from the contempt Venetians express against the Jews in their city. While both views 
seem to counter each other, they are not mutually exclusive. That Shylock is an alien already provides him with a universal connection to anyone who has endured such condition - Derrida argues that this connection would extend to everyone. Yet, that Shylock's alienation derives from his condition as a Jew should not be seen as limiting as Patrick Stewart makes him out to be, for to be singled out as a member of a group also extends as an experience beyond those who are Jewish.

Like Othello, Shylock fulfills Georg Simmel's model of the stranger who stayed. Yet, unlike the Moor, he is not provided with a background story to describe how he got to Venice. His story is known, as sufferance has been the badge of Jewish people within Christendom, and one that Elizabethan audiences were aware of, if only as perpetrators. Shakespeare imbues in Shylock the stateless condition Jewish people across Europe had suffered since the Roman Empire, greatly aggravated by the rise of Christianity. By the time of Queen Elizabeth I, the Jewish community had been banished from England for centuries. Further, Shylock's Venice was not the free haven for foreigners William Thomas had described in his History of Italy. The confinement to living in a ghetto and the other regulations imposed on Shylock's people seem to be a successfully implemented model of Brabantio's idealized Venice in Othello. Shylock is not seen by Venetians as "of Venice" for he is a Jew, and therefore only tolerated as "in Venice" because of his ascribed inherent Jewishness. 
Shylock's identity is problematic because, Antonio and the other Venetians, all embrace Stuart Hall's first model of cultural identity formation, as does Shylock. By essentializing Shylock through his Jewish heritage, Antonio and other Venetians find it easy to abuse and alienate Jews in what Venetians consider their city - a Christian city. If Stuart Hall's first model of cultural identity provides stability and "continuous frame of reference, and meaning" (Hall 223), then both polarizing sides in the play certainly justify their behavior by a claim to a unique ancestry. What they see as their own true selves is as irrevocable in them, as they see it crystalized in their object of othering. Homi Bhabha's concept of hybrid identities is somewhat difficult to apply in this play because both sides embrace their Barthian mythological claim to a Cartesian model of the self, refusing to admit the transforming effect their shared intersubjectivity in a positive way.

One of the antisemitic themes that informs Shylock's identity is associating his character with money as the driving force behind much of his thinking. His first line in the play is "three thousand ducats" (1.3.1), and when he is engaged with Antonio and Bassanio, he reflects on his hatred towards the former, not only because he is a Christian, "but more, for that in low simplicity he lends out money gratis and brings down the rate of usance here with us in Venice" (1.3.39-42). This is an accusation Antonio recalls in Act IV as the reason he gives Solanio for Shylock's unyielding desire to collect the forfeiture of the bond - Antonio "oft delivered from his forfeitures [Shylock's] many that have at times made moan" to the Venetian merchant (3.3.22-23). In Act II, once Shylock becomes aware that 
Jessica has eloped with Lorenzo, Solanio expresses his confusion to Salarino as he had "never seen a passion so confused... as the dog Jew did utter in the streets: My daughter! O my ducats! O my daughter!" (2.8.12-15). Further, in Act III, as Tubal reports not having found Jessica, Shylock bemoans the loss of a diamond worth two thousand ducats (3.1.77-78), and prior to that, in what may be one of Shakespeare's most famous speeches, Shylock justifies his revenge in part on Antonio hindering him half a million and laughing at or crippling his business dealings (3.1.51-52). These constant references to money play on the stereotype that has endured until modern times, and make Shylock representative of it, thus problematizing an argument for Shylock having a noble character.

"Hath a dog money?" (1.3.118). The question reverberates across the play as Shylock is repeatedly called dog by the likes of Gratiano and Solanio. Like the speech in Act IV ("Hath not a Jew eyes?"), here Shylock does not lay claim to possessing a noble character, but instead defends something far more fundamental - his humanity and the dignity that should be unalienable to it. Shylock accuses Antonio of spitting at him, insulting him, and openly displaying contempt towards his Jewish heritage. Yet, faced with a request for money, Shylock asks Antonio and Bassanio if he should dismiss the insults and say: "Fair sir, you spit on me on Wednesday last... you call me dog; and for these courtesies I'll lend you thus much moneys" (1.3.123-26). Antonio and Bassanio engage with Shylock within the identity they have crafted and forced him into - a disbeliever moneylender, something less than what it means to be Venetian. 
The critique to the Venetians' hypocrisy is reinforced by Antonio's admission that not only Shylock's accusation true, but that he will likely continue to transgress against him. Such dismissal of the other's humanity and claim to hospitality is accentuated by how other Venetians constantly refer to Antonio as a good person, indeed "the kindest man" (3.3.292). Antonio is, after all, a merchant of Venice. For Antonio, hospitality is not a welcome, but a tenuous tolerance towards a necessary evil, for he needs this devil, this evil soul that can even "cite scripture for his purpose" (1.3.96-97) as Antonio warns Bassanio. It can be argued that Bassanio's need and Antonio's willingness to engage with Shylock reflects how the City of Venice (London) engages with the strangers in their midst.

Shylock is not submissive against his oppressors, and his "arrogance reveals an attitude of defiance comparable to that of a (post)colonial subject trying to resist the colonizer's hegemony" (Maufort 40). He is not a good person, but Shakespeare presents him as a man surrounded by bad Christians, who have the upper hand as the dominant group and hosts in Venice. The rage and lack of compassion that Shylock displays is a product of the abuse he has endured, a mechanism of self-defense and survival. In Act IV Antonio thinks of financial reasons for Shylock's revenge (since a dog has fangs), and not for having systematically dehumanized him - even after Shylock has declared to him: "Thou call'dst me dog before thou hadst a cause" (3.3.6). Antonio's cause is for a homogeneous Venice where Shylock must be a Christian and there is no place for Judaism. 
Shylock is not a transient wanderer, for the play shows him as having settled firmly in Venice, but he is treated as such through both the physical separation of where he may live within the city, and how he is seen by Venetians. Indeed, it can be argued that Shylock does not live "in Venice," as the ghetto is a structure of separation and othering. Any attempt he might have made to be "of Venice" was treated as a transgression against the conditional hospitality he is offered. Yet, even though Shakespeare fully embraces the antisemitic stereotypes associated with Jews, he seems determined to provide Shylock with humanizing elements that, in a very subtle way, and perhaps even not purposely, potentially transform him into a victim. Despite how cruelly Shylock replies to Salarino's request to forgive Antonio's bond, not many lines before the man and his friend Solanio were mocking Shylock for his daughter Jessica having eloped with Lorenzo. The indignation at their mockery, the bad news he received from Tubal's search for Jessica, and Antonio's daily insults prior to having asked Shylock for money, set the stage for his outburst.

I am a Jew. Hath not a Jew eyes? Hath not a Jew hands, organs, dimensions, senses, affections, passions? - fed with the same food, hurt with the same weapons, subject to the same diseases, healed by the same means, warmed and cooled by the same winter and summer as a Christian is?

After having stated the abuses he has sustained from Antonio in the opening of the speech, Shylock proceeds to establish his identity as a human. Foreshadowing Derrida's dissolution of the host-stranger binary, Shylock reclaims a humanity that has been systematically denied by the Christians in 
Venice. If for Derrida hospitality precedes property, and the space the host claims as at-home and native is little more than "a 'land of asylum,' and hospitality" - given by one who is nothing more - or less - than a refugee who has ceased his wandering, a stranger who stayed (Raffoul 216), then at this moment Shylock is framing his identity as a human that belongs anywhere just as any other individual, for humanity precedes any other label.

The third part of the speech is as revealing as the first two, if somewhat more violent in tone.

If a Jew wrongs a Christian, what is His humility? Revenge. If a Christian wrong a Jew, what Should his sufferance be by Christian example? Why Revenge! The villainy you teach me I will execute, and it Shall go hard but I will better the instruction.

John Barton describes the performance of this speech as the tipping point, where an actor can make Shylock either a victim or a ruthless person (Barton). I argue that regardless of which angle is chosen by the actor, Shylock remains a victim, for his ruthlessness is born out of the abuse he has endured.

This example of mimicry, where Shylock emulates the Christian inhumanity that has been forced upon him, is a violent version of the critical term Homi Bhabha employs in his approach to identity formation within the "third space" created by hybridity. Shylock inhabits this ambivalent space, which for him has never been peaceful. In Othello there is a progressive escalation of violence that culminates with the total removal of the hybrid space that connects Othello with his Venetian identity. However, in Shylock's case, the in-between 
space has always been violent, and only brought to an outburst by the loss of his daughter. Those who inflict violence upon Shylock do so because he is a Jew, a stranger - they are not fueled by passion or envy, but like Brabantio in Othello, such rejection is based on a self-image of unadulterated identity, and a rejection of that which is not them. In tandem with the court scene that takes plays shortly after this speech, The Merchant of Venice presents a scenario that exemplifies a society that has traversed Derrida's views on the transgressive erasure of the host-guest mechanics of hospitality; neither side here desires the other's welcome nor wants to welcome the other.

Jessica is perhaps one of the most interesting and often overlooked characters in The Merchant of Venice. The reason for this academic slight may be attributed to her character's apparent existence within the romantic and comical themes of the play. However, I argue that Jessica is possibly one of the most important elements to better understand Shylock and Venice. She shares much with Othello's Desdemona, despite how little information is given about their past, beyond present happenings in the plays. Both women lack a mother figure, and are bound to their fathers in duty and obedience. However, while Desdemona becomes a tragic figure whose death may cause a wave of sadness across an audience, Jessica is often maligned as a heartless daughter, looking after her own interests. More than a character, Shakespeare seems to have crafted Jessica to be a multipurposed conduit of answers for the questions he raises about the stranger. Jessica's marriage to Lorenzo may have been seen by Shakespeare as the happier of the two solutions for Shylock's plight - the first 
being the forceful conversion of the Jew in Act IV, enabled by Portia and delivered by Antonio. Indeed, in the intermarriage of native and stranger "Shakespeare sees the only possible solution to the alien question problem" (Tretiak 407). Still, the solution itself remains problematic.

The stranger's plight in The Merchant of Venice is not one of race, but of culture and religion. If Othello's condition as an alien was accentuated by the color of his skin, Shylock and Jessica's condition was framed by their religion. While Shylock attempts to retain an unadulterated identity, much like Antonio does, Jessica is willing to embrace hybridity through marriage and conversion. She declares that her salvation lies in her husband (3.5.17). This salvation is her ability to inhabit a hybrid identity that allows her to receive Venice's conditional hospitality. Venetians in the play do not question Lorenzo's choice of Jessica as his wife, despite her being Shylock's daughter. Venice welcomes her as of Venice by marrying Lorenzo and converting to Christianity, as illustrated by the benefits given to her by the judgment in Act IV. This is a similar hybridity that the Duke of Venice and the Senate were willing to accept in Othello's marriage to Desdemona. The moral ambiguity of Jessica's actions is overlooked by all, because it serves the purpose of the native majority.

However, Shylock sees his daughter damned (dead) for becoming Lorenzo's wife. His sentiment is quite similar to Brabantio declaring Desdemona as dead when she has married Othello. Both parents reject their daughters' hybridization as it deviates from the purity that anchors their identity. Shylock's 
insistence that Jessica is his daughter, his flesh and his blood (3.1.32), is refuted by Salarino, who says they are nothing alike. Jessica may be "a daughter of his blood" only, not "to his manners" (Tretiak 406) . By renouncing Judaism, Jessica is no longer a threat to the common identity Venetians form around religion. This is a variation not unlike Brabantio's issue with Othello, for in his case, his idealized construct of Venice was predicated in a claim to a common ancestral heritage.

Perhaps the only scene that rivals in importance and power the scene of Shylock's famous "Hath not a Jew eyes?" speech, is that of Antonio's trial for the bond forfeiture in Act IV.

Therefore, Jew, Though justice be thy plea, consider this:

That in the course of justice none of us Should see salvation. We do pray for mercy, And that same prayer doth teach us all to render The deeds of mercy.

Portia's speech on mercy represents perhaps some of the most beautifully worded lines within the works of William Shakespeare, but such simple aesthetic praise would be misguided. To view Portia's mercy as a conciliatory attempt to erase, if for a moment, tensions in the play, is to have been seduced by her words on mercy, the double blessing that "droppeth as the gentle rain from heaven" (4.1.183). Is the mercy Portia attempts to extract from Shylock when she demands "then must the Jew be merciful...." the same mercy she asks from Antonio when she inquires, "What mercy can you render him, Antonio?" No. Here 
mercy is predicated in the mechanics of power between a dominant native population and the ostracized alien in their midst.

Portia presents to Shylock the opportunity to be merciful towards Antonio, granting the Jew access to a most Christian trait shared through birth and faith by most of those present at court - mercy. She is willing to acknowledge the humanity Shylock has claimed for himself earlier in the play; but only if he is willing to accept their conditional hospitality on Venice's terms. The mercy Portia offers to Shylock is the illusion of equality through compliance to the demands of the native majority. The latter sees through the hypocrisy at hand, for he asks Portia, "on what compulsion" must he be merciful (4.1.182), as all Venetians do not seem to be under similar obligation.

If Portia's version of mercy is that of compliance to the rule of a dominant native majority, the mercy Antonio offers to Shylock is of a more insidious nature. Antonio agrees with sparing the Jew's life and returns to Shylock one-half of the man's wealth that by law now belong to the merchant. Yet, in return for these favors, Antonio asks that Shylock becomes a Christian. Thus, Antonio engages in a similar mercy negotiation as Portia does prior to him - offering a mercy that can only be extended through compliance, but this time with the goal of acculturation and homogenization. Having almost died at Shylock's hands, all he asks is for the Jew to become a Christian, thus erasing the alien among them. Mercy in the Duke's courtroom is pronounced as "twice blest" (4.1.183). If so, within this scene mercy is also thrice betrayed: by Portia as previously 
mentioned, by Shylock who rejects mercy not on its merits or lack of them, but out of an unchecked desire for revenge, and finally by Antonio who uses mercy as a tool to erase the stranger.

Still, Shylock's prior rebuke on the grounds that he shares "the same physiology, faculties, emotions, and needs" as his tormentors turns him into "a spokesman for the ethical obligations that arise from our belonging to the same species" (Ryan 60). When Portia says that "in the course of justice, none of us should see salvation" (4.1.197-98) she is, perhaps inadvertently, making the case that something may, after all, be illegal and at the same time be morally permissible or praiseworthy, and that illegality may not necessarily translate into immorality. Portia is willing to break the bond that threatens Antonio's life under the law because he is of Venice, yet is unwilling to use the same principle when she applies the law to Shylock, for he is only in Venice.

Thus, although all fail to see the human in Shylock, and are only able to deal with the alien in front of them, it is Portia who ultimately maintains the line of Antonio's and Brabantio's Venice, where there is no space for Shylock or Othello. Portia leaves any semblance of mercy in tatters and engages in what Sir Thomas More would call "mountainish inhumanity," as she utters the words "Tarry, Jew! The law hath yet another hold on you" (4.1.345-46). When Antonio thought himself at Shylock's mercy prior to the trial, he contemplated the inevitability of his fate, for the Duke could not "deny the course of law, for the commodity that strangers have" in Venice. This is the same law that Portia later summons and 
twists, as having a hold on Shylock, declaring his life and property forfeit for having threatened the life of a Venetian. In doing so, Portia saves Antonio, but also reveals the inequality of the law towards the alien. The law is what had always kept Shylock behind the wall of the ghetto, away from being of Venice.

In the trial scene, Shakespeare seems to undo much of the effort he placed in humanizing the stranger that Shylock is a representation of. The Jew is left defeated and deprived of his identity, which may seem proper if the character is played as a bloodthirsty individual, and much of the rest of the play is forgotten. Yet, there should not be a "hasty conflation of Shakespeare's voice with his heroine's" as a way to impute upon the author racists tendencies (Maufort 41). Instead, the play shows that in the course of transgressing against the hospitality that ought to be given to the stranger, justice is also forsaken. 


\section{Shakespeare: Of or In Miami}

And we have asked for courage Not to belong, Not to identify, Not to regret.

Not to confide the spaces of our souls to the places of our first heart beat Not to let withering umbilical cords Keep us parched making more barren the strangeness of our foreign homes.

- Abena P.A. Busia, Testimonies Of Exile

"Universal my toe. Shakespeare is full of classicism, sexism, and defunct social mores" (O'Toole). While there is ample room for arguments regarding the nature of universality and English Renaissance plays, the elements Dr. O'Toole points out in her self-admitted anti-Shakespearean diatribe do describe what can be stamped as universal human experiences. That Shakespeare's plays may not necessarily be the most effective way to address social issues in the twenty-first century is certainly open to debate. Yet, it is the continuous reductive labeling, and the ongoing dismissive rejection of his works as irredeemably imperialist what remains problematic. From questioning authorial relevance to the significance of the language itself, to the various forms of creative discourse the works provoke among those who encounter them, William Shakespeare's plays, much to the dismay of some agenda-driven academics, remain a source of universal inspiration, and a catalyst that empowers the scrutiny of the very issues for which the plays are often faulted. 
An extraordinary number of pages have been devoted to the question of authorship. But, "what's in a name?" (Romeo and Juliet 2.2.44). To many, the name frames the author of the plays - English male, embodiment of colonial imperialism and academic elitism. It is through that power that Othello and The Merchant of Venice are taught to students across the United States and the world. Why? Because it is Shakespeare; as if the name alone provided reason enough for this apparent indoctrination. Thus, why write about it? Beyond the interest of literary scholars and historians, those who dismiss Shakespeare's works as an imperial text need to frame such an approach deep within Elizabethan historical context if only to have a clearly defined straw target to aim at. To the people with no skin in the authorship debate, or much interest in Elizabethan times, how the text speaks to them remains the true source of enjoyment and ultimate critique. After all, Miami, from where this paper originates, is not a homogeneous white audience such as one may find at a place like Stratford upon Avon, nor is it truly vested in upholding a strawman for the sake of national pride. Therefore, if the man behind the name is no longer relevant to a multicultural audience, then the text itself must be what Dr. Emer O'Toole decries as sexist, racist, and defunct.

Postcolonial theory "attempts to analyze the situation or conditions of production that determine the colonial Other" through the lens of resistance, subversion, and opposition, seeking to produce ideas that comment on concepts such as identity and liberty, which would be otherwise impossible to explore in a "colonized culture's view of society" (Popa 92). It is against what is considered 
imperialist or colonizing texts that this resistance or subversion is largely aimed, texts such as William Shakespeare's plays. Dr. Popa argues that formerly colonized cultures may struggle to develop distinct literatures of their own as a conduit to craft a national identity, and accurately points out that when achieved, this can only be a hybrid identity, given their irrevocable exposure to colonization. This is partly true for many of the groups that reside in multicultural cities like Miami. While they have no lack of distinct literature, as Latin America is fertile with exemplary works, their identity remains a hybrid, a mix of local roots and colonial influence. Dr. Popa's argument becomes precarious when she addresses the recent increased academic interest in the colonial aspects in Shakespearean works through "new perspectives on the author's celebration of the superiority of "civilized races," citing works such as Othello, The Merchant of Venice, Antony and Cleopatra, and The Tempest (Popa 93). While there can be no argument that these plays deal with issues of class and race, by accentuating Shakespeare as a playwright who celebrates racial superiority, Dr. Popa's argument becomes partially shallow and agenda driven. The presence of Homi Bhabha and Stuart Hall's concepts in Othello and The Merchant of Venice foreshadow "issues of hybridity and multiculturalism so typical of today's globalized world" (Maufort 39).

Much of Miami's population is made up of immigrants, exiles, and those who struggle in poverty. Their stories include encounters with racism and economic hardships, often exacerbated by their accent or the color of their skin the racially mixed, the transnational migrant, the gay household, the prostitute, 
the gypsy, the illegal immigrant that "threatens to bring chaos into the social order... provoking primitive fears of annihilation, of the dissolving of boundaries, and the dissolution of identity..." (Sandercock 111). In various ways they embody the experiences of characters like Othello and Shylock - interracial marriage remains here a common yet delicate subject, discrimination due to religion an unspoken reality, and the feeling of dispossession an all too familiar truth. Why then would Miami audiences ever care to attend one of Shakespeare's plays? One of the best answers for this question can be found in places such as Shylock's famous "Hath not a Jew eyes?" speech. What is often dismissed by post-colonial arguments is the humanity that William Shakespeare imbues in those characters that were originally intended to be merely the object of scorn or comedy. Shylock's words sharply declare a universality that is often denied to Shakespeare's works.

Despite abandoning their countries out of fear or extreme poverty, illegal immigrants face a process of dehumanization if found not to be compliant with the structures set by those in power. If those crossing the United States borders are not experiencing the right type of fear, the right type of persecution, or suffer the right type of necessity, they are not compliant, and therefore mercy cannot be extended to them. Thus, the mercy Portia is asking of Shylock in exchange for accepting his humanity is that of compliance: non-compliance is then illustrated by how Portia proceeds to strip Shylock out of everything, even up to the point of having him beg for his life. Such is the consequence of non-compliance - 
children separated from their parents, underpaid and overworked jobs, and deportations often for the smallest of errors.

Generations of those who inhabit places like Miami have experienced othering both in their home countries and wherever they have migrated to. Given Miami's large Jewish community, some may argue that they would find offensive any production of The Merchant of Venice. But such objections ought to be questioned, as the play illustrates a mistreatment that should not be forgotten, and Shylock's plight is palpable to the audience, not as the pain of a cartoon-like construct, but as the suffering of a human.

In the current political climate, the nationalist call for an endemic American identity based on fictitious racial constructs can be found lurking everywhere, in the lines of those who pretend to have some claim to normalcy, or overtly displayed in events such as the Virginia Unite the Right rally in August 2017. In past decades minority groups have endured an increased level of reactionary rejection by those who feel their identity and cultural purity was threatened. This is not only evident within the United States, but also through the resurgence of extreme-right movements throughout Europe, Asia, and Latin America; these have translated into a rejection of Islam as an acceptable religion, a resistance against embracing same-sex marriage as a normal family structure, and an aversion against immigration in general. Multiculturalism is seen by many as a threat to national identities; a concern that often drags moderate thinkers towards 
more extreme philosophies out of fear, and allows populist movements to gain first a foothold, then power.

The plays comment on the social reality that many experience, revealing the other within society; they do not exult in the superiority of a dominant group, but instead reveal the ugliness of the process. Some may argue that Shakespeare's works do not go far enough in their critique, thus entrenching the works in a distant past unaware of the other's plight. Yet, while there is a need for contemporary literature that aggressively tackles social issues, there is also room on the stage for plays such as The Merchant of Venice, where othering takes place, and victims that audiences can relate to end up dehumanized and destroyed, for such is often the nature of reality. Thus, William Shakespeare is of Miami, "of here and everywhere." His works remain relevant to social issues and universal towards the human condition. 
Works Cited

Bartels, Emily C. "The "stranger of here and everywhere": Othello and the Moor of Venice." Bartels, Emily C. Speaking of the Moor - From "Alcazar" to "Othello". University of Pennsylvania Press, 2008. pp. 155-190. Electronic. $<$ https://www.jstor.org/stable/j.ctt3fhngc.10>.

Barthes, Roland. Mythologies. New York: The Noonday Press, 1972. Print.

Busia, Abena P.A. Testimonies of Exile. New Jersey: Africa World Press, 1990. Print.

Byrne, Philippa. Why were the Jews expelled from England in 1290? Oxford, 2017. Electronic. <https://www.history.ox.ac.uk/::ognode62416::/files/teaching-resources-expulsion-jews>.

Cinthio, Giraldi. The Moor of Venice. Trans. J. E. Taylor. Ontario, 2000. Electronic. <http://www.yorku.ca/inpar/cinthio_moor_taylor.pdf>.

Conrad, Jospeh. Victory. Global Grey, 2018. Electronic. <https://www.globalgreyebooks.com/victory-ebook.html>.

Derrida, Jacques. Of Hospitality. Trans. Rachel Bowlby. Standord: Stanford University Press, 2000. Electronic.

Derrida, Jacques. Politics and Friendship - A Discussion with Jacques Derrida. with Geoffrey Bennington. University of Sussex: Centre for Modern French Thought. 1 December 1997. Electronic.

Dewes, Sir Sidmonds, ed. A Compleat Journal of the Votes, Speeches and Debates, both of the House of Lords and House of Commons. London: Paul Bowes, 1693. Electronic.

Easthope, Antony. "Homi Bhabha, Hybritidy and Identity, or Derrida versus Lacan." Hungarian Journal of English and American Studies (HJEAS) Vil. 4.No. 1/2 (1998): pp. 145-151. Electronic. <https://www.jstor.org/stable/41273996>.

Grossberg, Lawrence. Questions of Cultural Identity. Ed. Stuart Hall and Paul du Gay. SAGE Publications Ltd, 1996. Print.

Hall, Stuart. "Cultural Identity and Diaspora." International Migration Review 2 (January 1990): pp. 222-37. Electronic. <http://www.rlwclarke.net/Theory/SourcesPrimary/HallCulturalldentityandD iaspora.pdf>. 
Heilman, Robert B. Magic in the Web: Action and Language in Othello. Praeger, 1977. Print.

Hogan, Patrick C. "'Othello", Racism, and Despair." CLA Journal (1998): pp. 431451. Electronic. <https://www.jstor.org/stable/44323165>.

Kant, Immanuel. Perpetual Peace, A Philosophical Essay. London: George Allen \& Unwin LTD, 1795. Electronic.

Karakayali, Nedim. "The Uses of the Stranger: Circulation, Arbitration, Secrecy, and Dirt." Sage Journals (2006): pp. 312-330. Electronic. $<$ http://citeseerx.ist.psu.edu/viewdoc/download?doi=10.1.1.890.7527\&rep $=$ rep $1 \&$ type $=$ pdf $>$.

Kaufmann, Miranda. Black Tudors: The Untold Story. Oneworld Publications, 2017. Print. <http://www.mirandakaufmann.com/uploads/1/2/2/5/12258270/bbchmblac ktudors.pdf>.

Kundera, Milan. Ignorance. Harper Perenial, 2003. Print.

Lupton, Julia Reinhard. "Phenomenology and Hospitality: Macbeth's "Martlets: Shakespearean Phenomenologies of Hospitality." Criticism (Summer 2012): pp. 365-376. Electronic. <https://www.jstor.org/stable/23267667>.

Maclaren, Kym. "Intimacy as Transgression and the Problem of Freedom." Puncta Journal of Critical Phenomenology (2018): pp. 18-40. Electronic. $<$ http://journals.oregondigital.org/index.php/pjcp/article/view/PJCP.v1i1.3/4 432>.

Maufort, Marc. "Performing Europe's 'Others:' Towards a Postcolonial Reinterpretation of the Shakespeare Canon." Europa zwischen Fiktion und Realpolitik/L'Europe - fictions et réalités. Ed. Roland Marti and Henri Vogt. Transcript Verlag, 2010. pp. 35-52. Electronic. $<$ https://www.jstor.org/stable/j.ctv1fxjdn.5>.

O'Toole, Emer. "Shakespeare, universal? No, it's Cultural Imperialism." The Guardian 21 May 2012. Electronic.

Popa, Alina. "Post-Colonialism in Shakespeare's Works." Annals of the Constantin Brâncuși Issue 4 (2013): 92.

Raffoul, François. "The Subject of the Welcome: On Jacques Derrida's Adieu a Emmanuel Levinas." Symposium. Stanislaus: California State University, 1998. pp. 212-222. Electronic.

$<$ https://www.artsrn.ualberta.ca/symposium/files/original/72670ea211748e 23c49a337e21d99b78.PDF>. 
Ryan, Kiernan. Shakespeare's Universality: Here's Fine Revolution. Bloomsbury - The Arden Shakespeare, 2015. Print.

Salamon, Gayle. "What's Critical About Critical Phenomenology." PUNCTA Journal of Critical Phenomenology (2019): pp. 8-17. Electronic.

Sandercock, Leonie. Cosmopolis II: Mongrel Cities of the 21st Century. Continuum, 2003. Print.

Schott, Robin May. "Kant and Arendt on Hospitality." Jahrbuch für Recht und Ethik / Annual Review of Law and Ethics (2009): pp. 183-194. Electronic. $<$ https://www.jstor.org/stable/43593976>.

Shakespeare, William. Othello. The Complete Pelican Shakespeare. Ed. Russ McDonald. Penguin Books, 2002. 1392-1444. Print.

Shakespeare, William. The Merchant of Venice. The Complete Pelican Shakespeare. Ed. A. R. Braunmuller. Penguin Books, 2002. 285-323. Print.

Simmel, Georg. "On Individual." Georg Simmel on Individuality and Social Forms. Ed. Donald N. Levine. Chicago an dLondon: The University of Chicago Press, 1971. pp. 143-149. Electronic. <http://www.dartmouth.edu/ germ43/pdfs/simmel_stranger.pdf>.

Smith, lan. "Barbarian Errors: Performing Race in Early Modern England." Shakespeare Quarterly (Summer, 1998): pp.168-186. Electronic. <https://www.jstor.org/stable/2902299>.

Solzhenitsyn, Alexander. One Day in the Life of Ivan Denisovich. Signet, 2008.

Stewart, Patrick. RSC Playing Shakespeare Vo. 9 - Exploring a Character John Barton. 1984. Electronic.

Still, Judith. "Introduction to the question of hospitality: ethics and politics." Derrida and Hospitality. Edinburgh University Press, 2010. pp. 1-50. Electronic. <http://www.jstor.org/stable/10.3366/j.ctt1r20fq.5>.

Suchet, David. RSC Playing Shakespeare Vo. 9 - Exploring a Character John Barton. 1984. Electronic.

Thomas, William. "The libertee of straungers." The historie of Italie. Ann Arbor, $\mathrm{Ml}$; Oxford (UK), 1549. Electronic. $<$ http://name.umdl.umich.edu/A13726.0001.001>.

Tretiak, Adrew. "The Merchant of Venice and the "Alien" Question." The Review of English Studies Vol. 5.No. 20 (1929): pp. 402-409. Electronic. $<$ https://www.jstor.org/stable/508234>. 
UK National Archives. From Tolerance to Intolerance. 2018. Electronic. $<$ http://www.nationalarchives.gov.uk/pathways/blackhistory/early_times/eli zabeth.htm>.

Verdi, Giuseppe. "Otello." 1887. Electronic. <http://www.murashev.com/opera/Otello_libretto_English_Italian>.

Zohdi, Esmaeil. "Lost-identity; A Result of "Hybridity" and "Ambivalence" in Tayeb Salih's Season of Migration to the North." International Journal of Applied Linguistics and Literature Vol 7.No. 1 (2018): pp. 146-151. Electronic. 